\title{
The Role of Stress-Induced Changes of Homer1 Expression in Stress Susceptibility
}

\author{
Vasiliy V. Reshetnikov ${ }^{1,2, a *}$ and Natalia P. Bondar ${ }^{1,3}$ \\ ${ }^{1}$ Institute of Cytology and Genetics, Siberian Branch of the Russian Academy of Sciences, 630090 Novosibirsk, Russia \\ ${ }^{2}$ Sirius University of Science and Technology, 354340 Sochi, Russia \\ ${ }^{3}$ Department of Natural Sciences, Novosibirsk State University, 630090 Novosibirsk, Russia \\ ${ }^{a} e$-mail: vasiliyreshetnikov@bionet.nsc.ru
}

Received October 5, 2020

Revised February 25, 2021

Accepted March 5, 2021

\begin{abstract}
Stress negatively affects processes of synaptic plasticity and is a major risk factor of various psychopathologies such as depression and anxiety. HOMER1 is an important component of the postsynaptic density: constitutively expressed long isoforms HOMER1b and HOMER1c bind to group I metabotropic glutamate receptors MGLUR1 (GRM1) and MGLUR5 and to other effector proteins, thereby forming a postsynaptic protein scaffold. Activation of the GLUR1-HOMER1b,c and/or GLUR5-HOMER1b,c complex regulates activity of the NMDA and AMPA receptors and $\mathrm{Ca}^{2+}$ homeostasis, thus modulating various types of synaptic plasticity. Dominant negative transcript Homerla is formed as a result of activity-induced alternative termination of transcription. Expression of this truncated isoform in response to neuronal activation impairs interactions of HOMER1b,c with adaptor proteins, triggers ligand-independent signal transduction through MGLUR1 and/or MGLUR5, leads to suppression of the AMPA- and NMDA-mediated signal transmission, and thereby launches remodeling of the postsynaptic protein scaffold and inhibits long-term potentiation. The studies on animal models confirm that the HOMER1a-dependent remodeling most likely plays an important part in the stress susceptibility, whereas HOMER1a itself can be regarded as a neuroprotector. In this review article, we consider the effects of different stressors in various animal models on HOMER1 expression as well as impact of different HOMER1 variants on human behavior as well as structural and functional characteristics of the brain.
\end{abstract}

DOI: $10.1134 / \mathrm{S} 0006297921060018$

Keywords: stress, depression, synaptic plasticity, Homer1, metabotropic glutamate receptors

\section{INTRODUCTION}

Stress disrupts the balance between excitatory and inhibitory signals in the brain, which are mediated mainly by the changes in activity of the glutamatergic (excitatory) system and GABAergic (inhibitory) system. Disturbance of this balance leads to morphological changes and reorganization of the dendritic network in various brain structures [1]. Chronic deviations of the glutamate levels from the norm could play a key role in long-term structural and functional impairments of synaptic plasticity associated with various psychopathologies [2]. Aberrations of the

Abbreviations: AMPA receptor, $\alpha$-amino-3-hydroxy-5methyl-4-isoxazolepropionic acid receptor; LTD, longterm depression; LTP, long-term potentiation; MGLUR, metabotropic glutamate receptor; MGLUR1/5, group I metabotropic glutamate receptors; NMDA receptor, $\mathrm{N}$-methyl-D-aspartate glutamate receptor.

* To whom correspondence should be addressed. glutamatergic system activity are present in various psychiatric disorders such as depression [1-5], schizophrenia [6-8], and autism spectrum disorders [9].

The key role in the synaptic-plasticity alteration in response to stress is played by the postsynaptic-density proteins, which include receptor complexes, scaffold proteins, and adaptor proteins that are located predominantly in glutamatergic synapses. The postsynaptic-density proteins modulate signal transduction by combining synaptic signals from the presynaptic neurons and various neurotransmitter systems, mostly through N-methyl-Daspartate (NMDA) glutamate receptors and group I metabotropic glutamate receptors (MGLUR1 [also known as GRM1] and MGLUR5). Scaffold protein HOMER1 binds to MGLUR1, MGLUR5 [10], adaptor proteins (in particular to Shank family scaffold proteins [10]), phospholipase $C \beta[11,12], 1-4-5$-inositol triphosphate receptor [13, 14], TRPC channels [13, 14], ryanodine receptors (RyRs) [15], and selectively with $\mathrm{L}$ type $\mathrm{Ca}^{2+}$ channels [16], thereby regulating signal transmission, $\mathrm{Ca}^{2+}$ 
homeostasis, long-term potentiation (LTP), and longterm depression (LTD) $[17,18]$. Because the impaired glutamate transmission is observed in a variety of stressinduced psychopathologies, we have hypothesized that HOMER1 can be considered as an important component of stress susceptibility/resistance. Research in the last two decades indicates that changes in the expression of HOMER1 or its dominant negative isoform HOMER1a are observed in animals after restraint stress [19], social defeat stress [20], and in adult animals subjected to prenatal stress [21]. In addition, it has been shown that the expression of HOMER1 changes after treatment with anxiolytics or antidepressants [22]. Nonetheless, despite extensive investigation of the function of HOMER1 in synaptic plasticity, little is known about the role that the altered ratio of its isoforms plays in stress susceptibility and in stress-induced psychiatric disorders.

\section{STRUCTURE OF HOMER1}

HOMER1 has nine protein isoforms, three of them (HOMER1b, HOMER1c, and HOMER1d) are "long" isoforms that contain all functional domains, another two (HOMER1a and Ania3 [HOMER1m]) lack the C-terminal domain, and four isoforms (HOMERle, -f, -g, and -h) partially or completely lack both functional domains [23]. In our review, we will focus on the four most studied isoforms (HOMER1a, HOMER1b, HOMER1c, and Ania3) because only these have been reported to have functional significance.

In neurons at rest, the Homer 1 gene is transcribed into constitutively expressed transcripts Homer $1 b$ and/or Homer 1c. Neuronal activation stimulates formation of the short transcripts Homer $1 a$ and Ania3, which are immediate early transcripts; and expression of these isoforms ensures adaptation to stress at the molecular level. The mechanism of the expression switch from the long to short transcripts is not fully elucidated and is believed to be related to premature stalling of RNA polymerase II, mRNA cleavage, and polyadenylation of the formed $3^{\prime}-$ end [24]. It has been shown that the transcription factor MEF2 and the regulatory sequence TTGTTGGG (located near the site of transcription termination in short Homer 1 transcripts) are important for this process [24].

HOMER 1 contains a conserved region that includes the N-terminal EVH1 (WH1, RanBP1-WASP) domain, which binds to a consensus proline-rich sequence (ProPro-X-X-Phe), as well as to the so-called proline motif (P-motif): a sequence of 5 amino acid residues (Ser-ProLeu-Thr-Pro) [23]. EVH1 binds to a variety of adaptor proteins, receptors, and ligands (see [18, 23] for review). P-motif can also bind to the EVH1 domain, but EVH1 binding to Pro-Pro-X-X-Phe is stronger [25]. Therefore, $\mathrm{P}$-motif can bind to the neighboring EVH1 domains only in the absence of available Pro-Pro-X-X-Phe motifs, thus preventing multimerization of the HOMER1-receptor and/or HOMER1-effector protein complexes. Hence, P-motif is important for regulation of HOMER1 multimerization [25].

Additionally, the long isoforms (HOMER1b and HOMER1c) have a C-terminal coiled-coil (CC) domain, which mediates multimerization of these isoforms owing to the binding of specific motifs of the leucine zipper type to each other [26]. Isoforms HOMER1b and HOMER1c have similar structures and functions and differ only in a 12-amino-acid sequence, whose function is not fully understood (Fig. 1). Multimeric complexes of HOMER1b and/or HOMER1c (hereafter HOMER1b,c) are capable of binding to many different effector proteins, thus ensuring high velocity of synaptic transmission at the postsynaptic membrane. Transcripts Homerla and Ania 3 lack the sequence coding for the CC domain, while the $3^{\prime}$ untranslated region (3'-UTR) contains many AUUUA repeats that are characteristic of early response genes $[26,27]$. The presence of such repeats reduces mRNA stability and leads to its selective degradation [28]. The truncated transcripts contain 5-6 exons, in contrast to 10 in the full-length transcripts Homer $1 b$ and Homer $1 c$. Homerla and Ania 3 differ from each other in the C-terminal amino acid sequence (Fig. 1), and functional significance of these dissimilarities remains unclear too. Nevertheless, it should be noted that the expression patterns of Homer 1a and Ania3 mRNAs in response to neuronal activation are different: Homerla mRNA expression reaches its peak within an hour, whereas Ania3 mRNA expression peaks only after $4 \mathrm{~h}$ [29].

The absence of the $\mathrm{CC}$ domain in the isoforms HOMER1a and Ania3 does not allow them to form oligomeric complexes with each other, while the presence of the EVH1 domain enables these isoforms to bind to proline-rich motifs of various receptors, including MGLUR1 and/or MGLUR5 and adaptor proteins. Thus, both short isoforms serve as dominant negative genetic factors by capturing molecules that target HOMER $1 \mathrm{~b}$ and HOMER1c and causing dissociation of the protein complexes involving HOMER $1 b, c$ on the postsynaptic membrane. Disruption of the HOMER1b,c links under the influence of HOMER 1a leads to the decrease in the intracellular $\mathrm{Ca}^{2+}$ concentration [30] and to inhibition of the signal transduction pathways; both effects together contribute to postsynaptic-density remodeling. It should be pointed out that in many studies, short isoforms are not categorized into HOMER1a and Ania3, and the long ones into $\mathrm{b}$ and $\mathrm{c}$; therefore, the functions of individual isoforms remain poorly investigated.

\section{ROLE OF HOMER1 IN SYNAPTIC PLASTICITY}

The speed and duration of synaptic transmission and ability of the cell to respond appropriately to external 
Exon-intron boundaries of Homer1

ENSMUSG00000007617
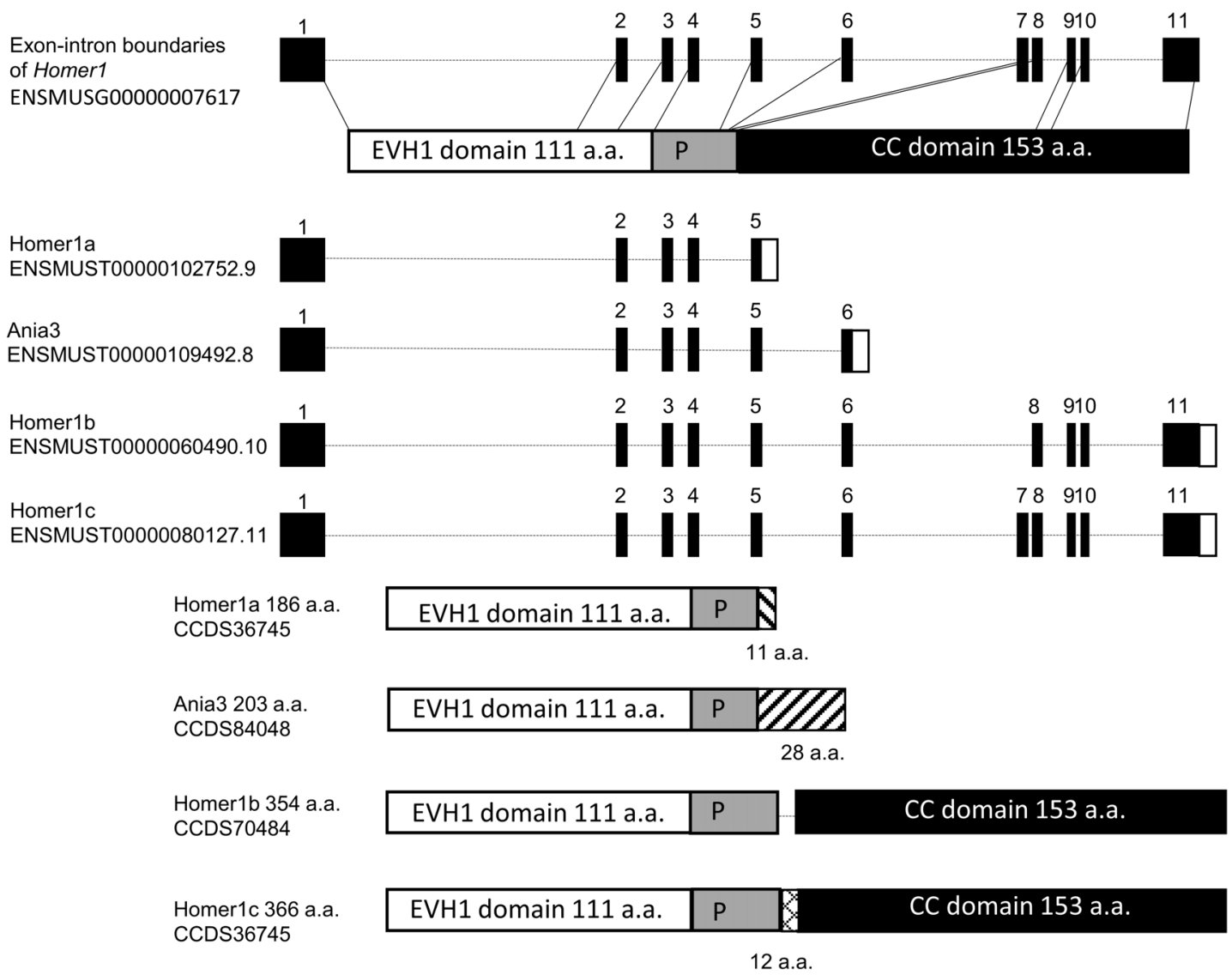

Fig. 1. Structures of Homer 1 transcripts (splice variants) and its protein isoforms. Homer 1 contains 11 exons. The first four exons encode the EVH1 domain, the 5th exon codes for the sequence containing P-motif ("P" in the figure); exons 8-11 encode the coiled-coil (CC) domain.

stimuli are integral characteristics of synaptic plasticity. Even though HOMER1 binds to many protein molecules, its most important role in synaptic plasticity is most likely related to its interaction with MGLUR1 and/or MGLUR5 [10, 17, 18, 26, 31]. Complexes MGLUR1HOMER1b,c and/or MGLUR5-HOMER1b,c play an important part in various types of synaptic plasticity, such as LTP [32], LTD [33-35], or depotentiation [36]. It is worth noting that the molecular mechanism underlying MGLUR1- and/or MGLUR5-mediated initiation of LTP is similar to that of LTD, and, in all likelihood, whether LTP or LTD gets triggered is determined by the activity of other components of the system [32]. Canonical MGLUR1 and MGLUR5 signal transmission proceeds through phospholipase $C$ activation by the $G_{q \alpha}$ subunit, which forms after dissociation of the heterodimeric complex of $G$ proteins MGLUR1 and MGLUR5 as a result of ligand binding to the receptor (Fig. 2a) [37]. Phospholipase C catalyzes hydrolysis of phosphoinositides with formation of inositol-1,4,5triphosphate (IP3) and diacylglycerol. IP3 binds to its receptors (IP3R) on the surface of endoplasmic reticulum and promotes $\mathrm{Ca}^{2+}$ release into the intracellular space; diacylglycerol, in turn, activates protein kinase C [38]. Both mechanisms underlie MGLUR1- and/or MGLUR5-mediated activation of signal transduction pathways via mitogen-activated kinase (MAPK), mTOR, and cAMP-CREB [38-40]. In addition, protein kinase C, just as $\mathrm{Ca}^{2+}$-induced kinase CAMK2B, directly phosphorylates $\mathrm{C}$-terminus of the $\alpha$-amino-3-hydroxy-5-methyl4-isoxazolepropionic acid receptor (AMPA receptor) subunits, thereby ensuring their stability on the postsynaptic membrane.

Agglomerates MGLUR1-HOMER1b,c and/or MGLUR5-HOMER1b,c are located at the periphery of the synapse, either in the perisynaptic region or embedded in the endoplasmic reticulum membrane [40, 41]. The multimeric HOMER1b,c complexes can form regulatory networks, such as MGLUR1/5-HOMER1b,cShank-GKAP-PSD95 through protein-protein interactions, the latter enhance efficiency of signal transduction through the N-methyl-D-aspartate glutamate receptor (NMDA receptors) and are structural components of the postsynaptic density [18, 42, 43]. Moreover, binding of the MGLUR1-HOMER1b,c and/or MGLUR5HOMER1b,c complex to endoplasmic-reticulum IP3R 


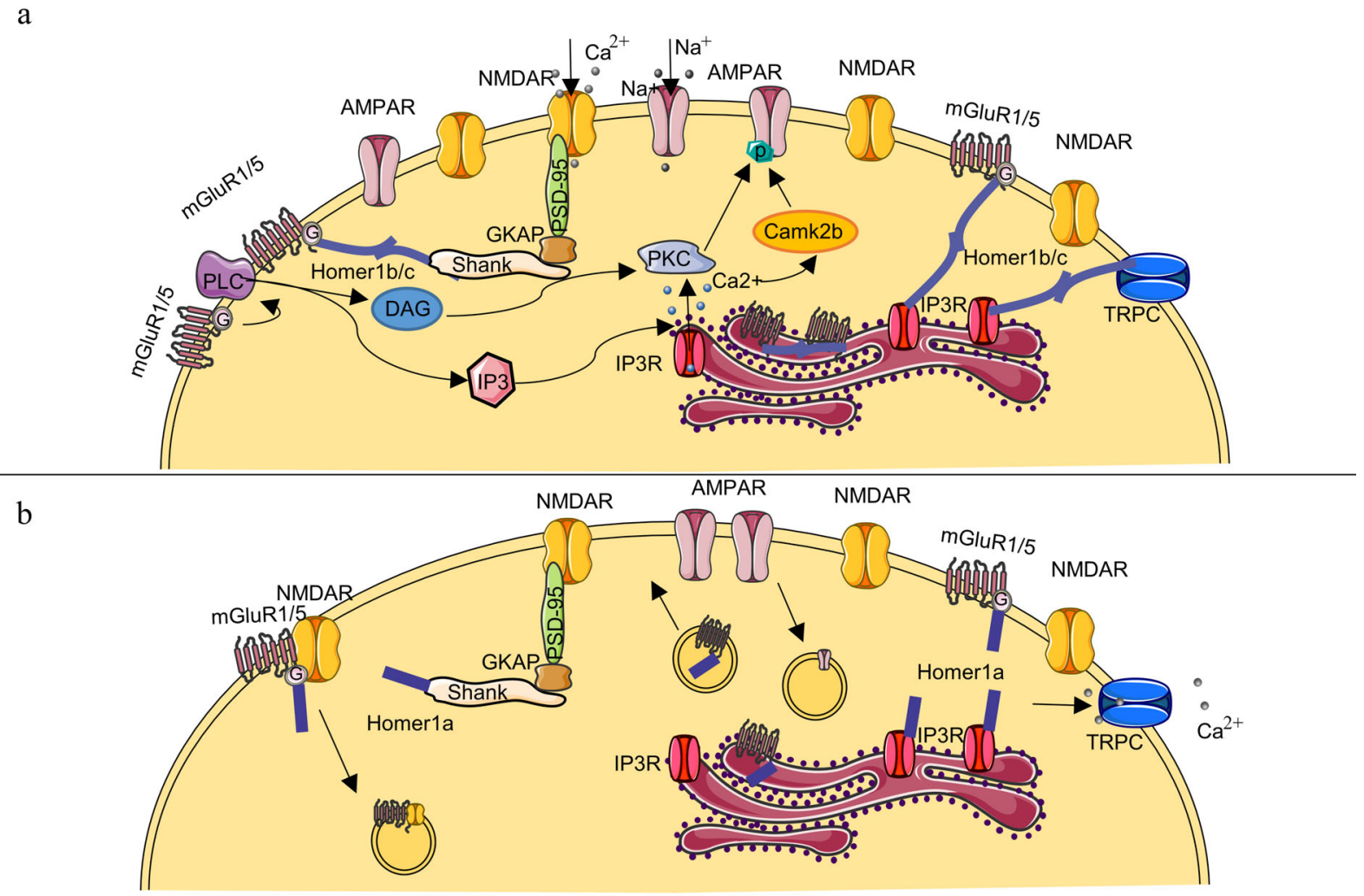

Fig. 2. Schematic representation of the postsynaptic membrane and role of HOMER1 in synaptic plasticity. a) The constitutively expressed HOMER1b or -c isoform ensures interconnection of MGLUR1 and/or -5 with NMDA receptors through protein-protein complexes Shank-GKAP-PSD95 and provides a link of MGLUR1 or -5 and TRPC calcium channels with IP3R on the postsynaptic membrane. Formation of HOMER $1 b, c$ scaffold with other proteins enables LTP and efficient signal transduction. $\mathrm{Ca}^{2+}$ release from its stores in the endoplasmic reticulum into the intracellular space leads to activation of the protein kinase CAMK2B, which, along with the protein kinase C, participates in phosphorylation of the $\mathrm{C}$-terminus of AMPA receptor subunits; this modification, in turn, prevents their endocytosis and promotes their stabilization on the postsynaptic-membrane surface. b) Molecular mechanisms underlying the HOMER1a-dependent synaptic-transmission downscaling. The short HOMER1a isoform competes with HOMER1b,c for binding sites, thereby disrupting multimeric complexes MGLUR1/5-HOMER1b,c-Shank and MGLUR1/5-HOMER1b,c-IP3R and switching MGLUR1 and/or -5 activation from liganddependent to ligand-independent mode. Complexes MGLUR1-HOMER1a and MGLUR5-HOMER1a are capable of inhibiting NMDA receptor activity through the $\beta$ subunit of the MGLUR1 or MGLUR5 G protein leading to their subsequent endocytosis. Decrease in the amounts of protein kinases reduces phosphorylation of the AMPA receptor subunits causing their endocytosis because the non-phosphorylated forms are less stable. (Colored versions of the figures are available in online version of the article and can be accessed at: https://www.springer.com/journal/10541)

ensures regulation of $\mathrm{Ca}^{2+}$ homeostasis [44]. Hence, interaction with various adaptor proteins in the postsynaptic density as well as the fact that HOMER1b,c is required for maturation of dendritic spines [44-46] suggest that HOMER1b,c helps to provide the necessary "backbone" of the postsynaptic density.

The short isoform HOMERla competes with HOMER $1 b, c$ for binding to adaptor proteins causing dissociation of the HOMER1b,c-Shank-GKAP-PSD95 agglomerates in a dose-dependent manner (Fig. 2b) [42]. Furthermore, binding of HOMERla to endoplasmicreticulum MGLUR1 and/or MGLUR5 leads to their transfer to the postsynaptic space [47], where they can directly inhibit signal transduction through the NMDA receptors via binding of the $\beta$-subunit of the MGLUR1 or MGLUR5 receptor $\mathrm{G}$ protein to the $\mathrm{C}$-terminus of the
NR1 subunit of NMDA receptor [48, 49]. Increase in the HOMER 1a expression and disruption of interactions HOMER1b,c-MGLUR1 and HOMER1b,c-MGLUR5 launch the ligand-independent activation of MGLUR1 and/or MGLUR5 [17, 47, 50]. This activation causes decrease in the number of AMPA receptors on the postsynaptic membrane owing to the reduced phosphorylation of the GLUA2 subunit of AMPA receptors and their increased endocytosis (see detailed review of the mechanism in $[17,18,50,51])$. The HOMER1a-induced reduction of the efficiency of synaptic transmission via MGLUR1 and MGLUR5 provides the basis for the socalled homeostatic synaptic plasticity, which is aimed at maintaining long-term stability of molecular networks [52]. Consequently, HOMER1a overexpression leads to remodeling of the postsynaptic density. Functionally, 
these changes are accompanied by LTP suppression and contribute to the decrease in synaptic-transmission efficiency $[53,54]$ and to the reduction in the synapse size and in the number of mature spines on a dendrite [46]. In contrast, some studies indicate that HOMER1a expression enhances synaptic transmission due to the glutamate-independent MGLUR5-mediated increase in the expression and in the number of AMPA receptors on the postsynaptic membrane $[55,56]$. The mechanism behind such activation of glutamatergic transmission is not clear because it was demonstrated in [56] and in other previous studies that the increased expression of HOMER1a induced dephosphorylation of the AMPA receptor subunits. It is assumed that dephosphorylation leads to the decrease in the number of AMPA receptors on the postsynaptic membrane [57]. Therefore, we believe that the claim that the enhanced expression of HOMER 1a results in the increase of AMPA-mediated signaling requires further verification. It is possible that the effects observed in these studies were caused by methodological details associated with the increase of the HOMER1a content. In particular, in the study [56] HOMER1a was synthesized in bacterial cells and delivered into neurons as part of the TAT-HOMER1a protein construct. We presume that this method of delivery of HOMER la into the cell could distort its effects on synaptic plasticity due to the fact of selective transport of HOMER1a only in some of the numerous different synapses [58].

\section{ACUTE STRESS INDUCES HOMER1A EXPRESSION}

Acute stress leads to neuronal activation and significantly raises the speed of Homer 1 transcription initiation with formation of the short transcripts Homerla and Ania3 [27]. It has been reported that acute stress in the contextual fear conditioning test results in a persistent increase in the Homerla expression in various regions of the hippocampus and amygdala; this change was observed already $30 \mathrm{~min}$ after the stress and persisted for up to $24 \mathrm{~h}$ $[59,60]$ (table). The stress caused by a predator fear also induces expression of the Homerla transcript in various brain regions such as hippocampus, hypothalamus, and amygdala [61]. Moreover, the level of Homerla expression in these brain structures correlates with the duration of the freezing reaction [61]. Similar changes were observed after a single exposure to social defeat stress in the adult male C57BL mice; these alterations did not lead to upregulation of the Homerla transcript by itself but decreased the levels of transcripts Homer $1 b$ and Homer $1 c$ (and probably changed the Homer1a/Homer $1 b /$ Homer $1 c$ ratio) in the dorsal hippocampus and were accompanied by impaired spatial memory [20]. On the other hand, these negative effects of stress on spatial memory were neutralized either by the targeted overexpression of tran- scripts Homer $1 b$ and Homer $1 c$ in the dorsal hippocampus or by administration of the MGLUR5 antagonist (3-2methyl-4-thiazolyl-ethynyl-pyridine, MTEP) $5 \mathrm{~min}$ before the initiation of the social defeat stress [20]. In rats shocked with an electric current (foot shock), Homer $1 b$ and Homerlc expression in the prefrontal cortex was found to be reduced $24 \mathrm{~h}$ after the exposure [62]. In general, induction of the HOMER1a isoform expression regardless of the type of stress is in good agreement with the results of other studies, which have shown that Homer la induction is observed in response to various types of stimuli, such as chemically induced neuronal depolarization, epileptic activity, physical injury, administration of psychostimulants, physical activity, and the stress caused by adverse environmental factors or new environment (for review see [18, 22]). It can be concluded that the induction of HOMERla expression during acute stress is nonspecific and probably takes part in the LTP suppression and in postsynaptic-density remodeling.

\section{PARTICIPATION OF HOMER1 IN ADAPTATION TO CHRONIC STRESS}

Chronic stress also affects the levels of expression of various HOMER1 isoforms. For instance, in rats subjected to chronic restraint stress ( $6 \mathrm{~h} /$ day for 21 days), the amounts of isoforms HOMER1b and -c [63] and the levels of their mRNAs [19] increased in the hippocampus $18 \mathrm{~h}$ after the last exposure to stress. Similar changes in the expression of Homer $1 b$ and $-c$ in the dorsal hippocampus were observed after chronic social defeat stress [64]. In addition, it was demonstrated in [64] that chronic social defeat stress decreased the number of HOMER1b,c complexes with MGLUR5 as compared to the control group, although the amounts of HOMER1b, HOMER1c, and MGLUR5 were similar between the groups. An elegant study on mice [65] has revealed that animals susceptible to chronic social defeat stress and animals subjected to chronic restraint stress displayed similar increase in the mRNA and protein expression of HOMER $1 b$ and HOMER1c in the hippocampus, regardless of the type of stress. In that study, expression levels of HOMER1b and HOMER1c negatively correlated with the parameters of social behavior (social interaction ratio) and positively correlated with the parameter of depressive-like behavior (sucrose preference), which were assessed in these animals after exposure to chronic stress. Besides, the authors of that study demonstrated that in animals susceptible to chronic social defeat stress, there was enhancement of the MGLUR-mediated LTD and reduced expression of the AMPA receptor subunits (GLUA1 and GLUA2). Accordingly, those authors suggest that the increase in the MGLUR-HOMER1b,cmediated signaling drives $\mathrm{Ca}^{2+}$ release from endoplasmic reticulum, and this $\mathrm{Ca}^{2+}$ activates PERK-eIF2 $\alpha$ and the 
Stress-induced changes in HOMER1 expression

\begin{tabular}{|c|c|c|c|c|c|c|c|c|}
\hline $\begin{array}{l}\text { Species } \\
\text { (strain) }\end{array}$ & $\begin{array}{l}\text { Age/sex } \\
\text { during } \\
\text { stress }\end{array}$ & $\begin{array}{l}\text { Stressor } \\
\text { type }\end{array}$ & Stress duration & $\begin{array}{l}\text { Timing of } \\
\text { sampling }\end{array}$ & $\begin{array}{l}\text { Brain } \\
\text { structure }\end{array}$ & Method & Expression of HOMER1 & Reference \\
\hline $\begin{array}{l}\text { Rats } \\
\text { (Lister } \\
\text { hooded) }\end{array}$ & adults $\hat{\jmath}$ & $\begin{array}{l}\text { contextual } \\
\text { fear condi- } \\
\text { tioning }\end{array}$ & one-time & $\begin{array}{l}\text { in } 30 \mathrm{~min} \\
1 \mathrm{~h} ; 4 \mathrm{~h} \\
24 \mathrm{~h}\end{array}$ & $\begin{array}{l}\text { areas CA1, } \\
\text { CA3, and } \\
\text { DG dHIP } \\
(-3.5 \mathrm{~mm} \\
\text { relative to } \\
\text { Bregma) }\end{array}$ & in situ & $\begin{array}{l}\text { Homer } 1 b \text { and Homer } 1 c \\
\text { unchanged in all tested } \\
\text { regions; Homer } 1 a \uparrow \text { in CA1 } \\
\text { in } 30 \text { min, } 2 \text {, and } 4 \text { h; } \\
\uparrow \text { in DG in } 30 \text { min; Ania } 3 \uparrow \\
\text { in CA1, CA } 3 \text { and DG } \\
\text { in } 30 \text { min }\end{array}$ & [59] \\
\hline $\begin{array}{l}\text { Mice } \\
\text { (C57BL/ } \\
6 \mathrm{~J})\end{array}$ & $\begin{array}{l}\text { adults } \\
(6-10 \mathrm{w}) \curvearrowright\end{array}$ & $\begin{array}{l}\text { contextual } \\
\text { fear condi- } \\
\text { tioning }\end{array}$ & one-time & in $2 \mathrm{~h}$ & HIP; AMY & qPCR & $\begin{array}{l}\text { Homerla } \uparrow \text { both in HIP } \\
\text { and in AMY; Homerlc } \\
\text { unchanged }\end{array}$ & {$[60]$} \\
\hline $\begin{array}{l}\text { Rats } \\
\text { (Sprague- } \\
\text { Dawley) }\end{array}$ & adults $\hat{\jmath}$ & $\begin{array}{l}\text { exposure to } \\
\text { predator }\end{array}$ & one-time for $15 \mathrm{~min}$ & in $1 \mathrm{~h}$ & $\begin{array}{l}\text { PVN (Bregma } \\
-1.80 \mathrm{~mm}) \\
\text { AMY, DG, } \\
\text { CA1, CA3 } \\
\text { (Bregma } \\
-3.14 \mathrm{~mm})\end{array}$ & in situ & $\begin{array}{l}\text { Homerla } \uparrow \text { in all brain } \\
\text { structures }\end{array}$ & {$[61]$} \\
\hline $\begin{array}{l}\text { Mice } \\
(\mathrm{C} 57 \mathrm{BL} / \\
6 \mathrm{~N})\end{array}$ & $\begin{array}{l}\text { adults } \\
(12 \mathrm{w}) \hat{\jmath}\end{array}$ & $\begin{array}{l}\text { social defeat } \\
\text { stress }\end{array}$ & one-time for $5 \mathrm{~min}$ & $\begin{array}{l}\text { in } 1 \mathrm{~h} ; 4 \mathrm{~h} \\
8 \mathrm{~h} ; 24 \mathrm{~h}\end{array}$ & $\begin{array}{l}\text { CA1 area } \\
\text { of HIP }\end{array}$ & in situ & $\begin{array}{l}\text { Homer } 1 a \text { unchanged at any } \\
\text { time point; Homer } 1 b \\
\text { and/or -c } \downarrow \text { in } 4 \text { and } 8 \mathrm{~h}\end{array}$ & [20] \\
\hline $\begin{array}{l}\text { Rats } \\
\text { (Sprague- } \\
\text { Dawley) }\end{array}$ & adults $\lesssim$ & foot shock & $40 \mathrm{~min}$ & $\begin{array}{l}\text { in } 1 \mathrm{~d} \\
7 \mathrm{~d} ; 14 \mathrm{~d}\end{array}$ & HIP & $\begin{array}{l}\text { qPCR; } \\
\text { Western } \\
\text { blotting }\end{array}$ & $\begin{array}{l}\text { protein HOMER } 1 \uparrow \text { in } 7 \\
\text { days, Homer } 1 b \text { and }-\mathrm{c}=\end{array}$ & [105] \\
\hline $\begin{array}{l}\text { Rats } \\
\text { (Sprague- } \\
\text { Dawley) }\end{array}$ & adults $\hat{\sigma}$ & foot shock & $40 \mathrm{~min}$ & $\begin{array}{l}\text { in } 24 \mathrm{~h} ; \\
7 \mathrm{~d} ; 14 \mathrm{~d}\end{array}$ & mPFC & qPCR & $\begin{array}{l}\text { Homer } 1 b \text { and/or -c } \downarrow \\
\text { in } 24 \mathrm{~h}\end{array}$ & {$[62]$} \\
\hline $\begin{array}{l}\text { Rats } \\
\text { (Wistar) }\end{array}$ & adults $\hat{\sigma}$ & $\begin{array}{l}\text { restraint } \\
\text { stress }\end{array}$ & $\begin{array}{l}\text { repeated at } 6 \mathrm{~h} / \mathrm{d} \\
\text { for } 21 \mathrm{~d}\end{array}$ & in $18 \mathrm{~h}$ & HIP & $\begin{array}{l}\text { Western } \\
\text { blotting }\end{array}$ & HOMER $1 b$ and/or -c $\uparrow$ & {$[63]$} \\
\hline $\begin{array}{l}\text { Rats } \\
\text { (Wistar) }\end{array}$ & adults $\hat{\sigma}$ & $\begin{array}{l}\text { restraint } \\
\text { stress }\end{array}$ & $\begin{array}{l}\text { repeated at } 6 \mathrm{~h} / \mathrm{d} \\
\text { for } 21 \mathrm{~d}\end{array}$ & in $18 \mathrm{~h}$ & HIP & qPCR & Homer $1 b$ and/or c $\uparrow$ & [19] \\
\hline $\begin{array}{l}\text { Mice } \\
(\mathrm{C} 57 \mathrm{BL} / \\
6 \mathrm{~N})\end{array}$ & $\begin{array}{l}\text { adults } \\
(12 \mathrm{w}) \lesssim\end{array}$ & $\begin{array}{l}\text { social defeat } \\
\text { stress }\end{array}$ & $\begin{array}{l}\text { repeated once a day } \\
\text { for } 21 \mathrm{~d}\end{array}$ & in $24 \mathrm{~h}$ & $\begin{array}{l}\text { DG, CA1, } \\
\text { CA3 areas } \\
\text { of dHIP }\end{array}$ & in situ & $\begin{array}{l}\text { Homer } 1 b \text { and/or -c } \uparrow \text { in } \\
\text { CA1, CA3; Homer } 1 a \\
\text { unchanged }\end{array}$ & {$[64]$} \\
\hline $\begin{array}{l}\text { Mice } \\
\text { (C57BL/ } \\
6 \mathrm{~J})\end{array}$ & $\begin{array}{l}\text { adults } \\
(7-8 \mathrm{w}) \hat{ठ}\end{array}$ & $\begin{array}{l}\text { social defeat } \\
\text { stress; } \\
\text { restraint } \\
\text { stress }\end{array}$ & $\begin{array}{l}\text { repeated once a day } \\
\text { for } 10 \mathrm{~d} \text {; repeated } \\
\text { at } 2 \mathrm{~h} / \mathrm{d} \text { for } 21 \mathrm{~d}\end{array}$ & $\begin{array}{l}\text { in } 120 \mathrm{~h} \text {; } \\
\text { in } 72 \mathrm{~h}\end{array}$ & $\begin{array}{l}\text { mPFC, HIP, } \\
\text { AMY; HIP }\end{array}$ & $\begin{array}{l}\text { qPCR; } \\
\text { Western } \\
\text { blotting }\end{array}$ & $\begin{array}{l}\text { HOMER } 1 \mathrm{~b} \text { and/or -c } \uparrow \text { in } \\
\text { HIP in animals susceptible } \\
\text { to social defeat stress; } \\
\text { HOMER } 1 \text { a unchanged; } \\
\text { HOMERlb and/or -c } \uparrow \text { HIP }\end{array}$ & {$[65]$} \\
\hline $\begin{array}{l}\text { Rats } \\
\text { (Wistar) }\end{array}$ & $\begin{array}{l}\text { adults } \\
\text { (weight } \\
170 \mathrm{~g} \text { ) } \delta\end{array}$ & $\begin{array}{l}\text { chronic } \\
\text { mild stress }\end{array}$ & repeated for $42 \mathrm{~d}$ & $\mathrm{n} / \mathrm{a}$ & FC & qPCR & Homer $1 b$ and/or -c $\downarrow$ & [68] \\
\hline $\begin{array}{l}\text { Rats } \\
\text { (Wistar) }\end{array}$ & $\begin{array}{l}\text { adolescents } \\
(5-6 \mathrm{w}) \hat{\jmath}\end{array}$ & $\begin{array}{l}\text { chronic } \\
\text { mild stress }\end{array}$ & repeated for $56 \mathrm{~d}$ & $\mathrm{n} / \mathrm{a}$ & mPFC & proteomics & HOMER $1 b$ and/or -c $\uparrow$ & [69] \\
\hline $\begin{array}{l}\text { Mice } \\
\text { (C57BL/ } \\
6 \mathrm{~J})\end{array}$ & $\begin{array}{l}\text { adults } \\
(8-10 \mathrm{w}) \widehat{ठ}\end{array}$ & $\begin{array}{l}\text { chronic } \\
\text { mild stress }\end{array}$ & repeated for $57 \mathrm{~d}$ & in $120 \mathrm{~h}$ & HIP; PFC & $\begin{array}{l}\text { Western } \\
\text { blotting }\end{array}$ & $\begin{array}{l}\text { HOMER1a } \downarrow \text { in HIP } \\
\text { and PFC }\end{array}$ & {$[66]$} \\
\hline $\begin{array}{l}\text { Mice } \\
(\mathrm{C} 57 \mathrm{BL} / \\
6 \mathrm{~J})\end{array}$ & $\begin{array}{l}\text { adults } \\
(15-16 \mathrm{w}) \precsim\end{array}$ & $\begin{array}{l}\text { social defeat } \\
\text { stress; com- } \\
\text { bination of } \\
\text { early post- } \\
\text { natal stress } \\
\text { and social } \\
\text { defeat stress } \\
\text { at adult age }\end{array}$ & $\begin{array}{l}\text { social defeat stress } \\
\text { once a day for } 15 \mathrm{~d} \text {; } \\
\text { early postnatal: } \\
\text { separation of pups } \\
\text { from mothers for } 3 \mathrm{~h} \\
\text { once a day from } \\
\text { postnatal day } 2 \text { to } \\
\text { postnatal day } 14\end{array}$ & $\begin{array}{l}\text { at } 48 \mathrm{~h} \\
\text { after last } \\
\text { social } \\
\text { confront- } \\
\text { ation }\end{array}$ & PFC & $\begin{array}{l}\text { RNA-seq; } \\
\text { qPCR }\end{array}$ & $\begin{array}{l}\text { Homerla } \downarrow \text { in combined- } \\
\text { stress group }\end{array}$ & [67] \\
\hline
\end{tabular}


Table (Contd.)

\begin{tabular}{|c|c|c|c|c|c|c|c|c|}
\hline $\begin{array}{l}\text { Species } \\
\text { (strain) }\end{array}$ & $\begin{array}{c}\text { Age/sex } \\
\text { during } \\
\text { stress }\end{array}$ & $\begin{array}{c}\text { Stressor } \\
\text { type }\end{array}$ & Stress duration & $\begin{array}{l}\text { Timing of } \\
\text { sampling }\end{array}$ & $\begin{array}{l}\text { Brain } \\
\text { structure }\end{array}$ & Method & Expression of HOMER1 & Reference \\
\hline $\begin{array}{l}\text { Mice } \\
\text { (C57BL/ } \\
6 \mathrm{~J})\end{array}$ & $\begin{array}{l}\text { adults } \\
(12-15 \mathrm{w})\end{array}$ & $\begin{array}{l}\text { early post- } \\
\text { natal stress }\end{array}$ & $\begin{array}{l}\text { separation of pups } \\
\text { from mothers for } \\
15 \text { or } 180 \text { min once } \\
\text { a day from postna- } \\
\text { tal day } 2 \text { to postna- } \\
\text { tal day } 14\end{array}$ & $\begin{array}{l}\text { at adult } \\
\text { age }\end{array}$ & $\begin{array}{l}\text { dHIP (Bregma } \\
-1.86 \text { to } \\
-2.16 \mathrm{~mm}) \\
\text { PFC }\end{array}$ & qPCR & $\begin{array}{l}\text { Homer } 1 a=\text { in both } \\
\text { groups; Homer } 1 b \\
\text { and }-\mathrm{c}=\text { in both groups }\end{array}$ & [74] \\
\hline $\begin{array}{l}\text { Mice } \\
\text { (C57BL/ } \\
6 \mathrm{~J})\end{array}$ & $\begin{array}{l}\text { adults } \\
(12-15 \mathrm{w}) \partial\end{array}$ & $\begin{array}{l}\text { early post- } \\
\text { natal stress }\end{array}$ & $\begin{array}{l}\text { separation of pups } \\
\text { from mothers for } \\
180 \text { min once a day } \\
\text { from postnatal day } \\
2 \text { to postnatal day } \\
14 \text {; one-time sepa- } \\
\text { ration from moth- } \\
\text { ers for } 24 \text { h on } \\
\text { postnatal day } 9\end{array}$ & $\begin{array}{l}\text { at adult } \\
\text { age }\end{array}$ & PFC & RNA-seq & $\begin{array}{l}\text { in chronic postnatal stress } \\
\text { group: Homer } 1 \downarrow, \text { but } \\
\text { Homer } 1 a \text { and Homer } 1 b \\
\text { and -c unchanged individu- } \\
\text { ally; in one-time separation } \\
\text { group: Homer } 1, \text { Homer } 1 a, \\
\text { Homer } 1 b \text { and -c = }\end{array}$ & $\begin{array}{l}\text { unpublished } \\
\text { results, NCBI } \\
\text { BioProject } \\
\text { PRJNA649640 }\end{array}$ \\
\hline $\begin{array}{l}\text { Mice } \\
(\mathrm{C} 57 \mathrm{BL} / \\
6 \mathrm{~J})\end{array}$ & $\operatorname{pups}_{\lambda}(15 \mathrm{~d})$ & $\begin{array}{l}\text { early post- } \\
\text { natal stress }\end{array}$ & $\begin{array}{l}\text { separation of pups } \\
\text { from mothers for } \\
180 \text { min once a day } \\
\text { from postnatal day } \\
2 \text { to postnatal day } \\
14 \text {; one-time sepa- } \\
\text { ration from moth- } \\
\text { ers for } 24 \text { h on } \\
\text { postnatal day } 9\end{array}$ & $\begin{array}{l}\text { on post- } \\
\text { natal day } \\
15\end{array}$ & PFC & RNA-seq & $\begin{array}{l}\text { both in one-time separation } \\
\text { group and in repeated sepa- } \\
\text { ration group: Homer } 1 \text {, } \\
\text { Homerla, Homer } 1 b \\
\text { and }-\mathrm{c}=\end{array}$ & $\begin{array}{l}\text { unpublished } \\
\text { results, NCBI } \\
\text { BioProject } \\
\text { PRJNA649640 }\end{array}$ \\
\hline $\begin{array}{l}\text { Rats } \\
\text { (Sprague- } \\
\text { Dawley) }\end{array}$ & 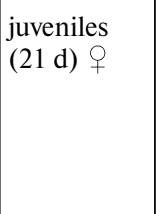 & $\begin{array}{l}\text { prenatal } \\
\text { stress com- } \\
\text { bined with } \\
\text { restraint } \\
\text { stress for } \\
\text { mothers }\end{array}$ & $\begin{array}{l}\text { repeated ( } 3 \text { times a } \\
\text { day for } 30 \text { min dur- } \\
\text { ing last } 7 \mathrm{~d} \text { of ges- } \\
\text { tation) }\end{array}$ & $\begin{array}{l}\text { on post- } \\
\text { natal day } \\
21\end{array}$ & $\begin{array}{l}\text { AMY; HIP; } \\
\text { PFC }\end{array}$ & $\begin{array}{l}\text { Western } \\
\text { blotting }\end{array}$ & $\begin{array}{l}\text { HOMER } 1 \mathrm{a} \uparrow \text { in AMY, HIP, } \\
\text { and PFC; HOMER1b } \\
\text { and/or -c } \uparrow \text { in PFC }\end{array}$ & [73] \\
\hline $\begin{array}{l}\text { Rats } \\
\text { (Sprague- } \\
\text { Dawley) }\end{array}$ & $\begin{array}{l}\text { adults } \\
(17 \mathrm{w}) \hat{ठ}\end{array}$ & $\begin{array}{l}\text { prenatal } \\
\text { stress com- } \\
\text { bined with } \\
\text { restraint } \\
\text { stress for } \\
\text { mothers }\end{array}$ & $\begin{array}{l}\text { repeated ( } 3 \text { times a } \\
\text { day for } 45 \text { min } \\
\text { starting from day } \\
11 \text { of pregnancy) }\end{array}$ & $\begin{array}{l}\text { at adult } \\
\text { age }\end{array}$ & $\begin{array}{l}\text { AMY; dHIP; } \\
\text { PFC }\end{array}$ & in situ & $\begin{array}{l}\text { Homer } 1 a \uparrow \text { AMY and } \downarrow \\
\text { in HIP and PFC; } \\
\text { Homer } 1 b \text { and/or -c } \downarrow \text { in } \\
\text { AMY }\end{array}$ & {$[21]$} \\
\hline
\end{tabular}

Notes. PVN, paraventricular nuclei of the hypothalamus; AMY, amygdala; FC, frontal cortex; HIP, hippocampus; dHIP, dorsal hippocampus; PFC, prefrontal cortex; mPFC, medial prefrontal cortex; qPCR, quantitative PCR; RNA-seq, high-throughput RNA sequencing; $\uparrow$, increased expression; $\downarrow$, decreased expression; =, unchanged expression; N/A, no data.

CREB signaling pathway in the hippocampus (the amounts of phosphorylated forms of PERK, eIF2 $\alpha$, and CREB are higher in the group susceptible to stress). Similar effects have been reported in the model of chronic mild stress, which downregulated HOMER1a in the hippocampus and prefrontal cortex, and this decrease was accompanied by the pronounced depression-like phenotype in the animals [66]. The prolonged exposure to highfrequency transcranial magnetic stimulation $(15$ or $25 \mathrm{~Hz}$ from day 30 to day 57 of stress), which stimulates the activity of brain neurons and is used in the treatment of various neurological and mental disorders, attenuates the effects of stress both on behavior and on HOMER1a expression in various brain structures [66]. Given that HOMER1a is known to be a dominant negative isoform, it can be assumed that the decrease in its amount enhances HOMER1b,c-mediated signaling. The similar decrease in Homer 1 expression in the prefrontal cortex of adult male mice exposed to chronic social defeat stress and explained mainly by downregulation of HOMER1a expression was noted in our work [67].

Nonetheless, not all brain structures show similar effects of chronic stress on the HOMER1a/HOMER1b/ HOMER1c ratio. In the abovementioned study [65], the animals exposed to chronic social defeat stress manifested changes in the expression of HOMER $1 \mathrm{~b}$ and HOMER1c only in the hippocampus, while the levels of HOMER1b, HOMER1c, and HOMER1a remained unchanged in the prefrontal cortex and amygdala. Chronic mild stress for six weeks led to the decrease in 
Homer1b and Homer1c levels in the frontal cortex [68]. Besides, proteomic analysis revealed that the HOMER $1 \mathrm{~b}$ and HOMER1c levels in the prefrontal cortex are higher in the rats resistant to chronic mild stress, than in the susceptible animals [69]. It can be suggested that such differences in the effects of chronic stress on HOMER1 could be related to the region specificity of these phenomena, methodological differences, the type of stress, and different methods for protein quantitation. We can conclude that the most reproducible effects of various types of chronic stress involve upregulation of HOMER1b,c and decrease in the HOMER1a/HOMER1b/HOMER1c ratio in hippocampus, and these molecular changes are directly related to the susceptibility/resistance of animals to chronic stress.

\section{DELAYED EFFECTS OF STRESS ON HOMER1 EXPRESSION}

Stress early in life (prenatal and early postnatal periods) can affect stress susceptibility in adolescence and adulthood. Molecular mechanisms underlying these delayed effects of stress are most likely associated with epigenetic changes that alter the pattern of gene expression [70, 71]. Homer 1a expression in cortical structures and in hippocampus increases gradually after birth and reaches peak in the 3 rd postnatal week in rodents [31, 72]. This process coincides with the period of intense reorganization of synapses and establishment of the stable synaptic networks. In a study on rats, it was found that chronic stress during prenatal period increased mRNA and protein expression of Homer la in the amygdala in the juvenile and adult animals [21, 73]. By contrast, the level of Homer1a in hippocampus and prefrontal cortex was high in the juvenile animals [73] and low in adults [21]. Homerla expression in the hippocampus and prefrontal cortex directly correlated with the time spent in a light zone in the light-dark box test, while its expression in the amygdala correlated with this parameter inversely [21]. Our research on models of early postnatal stress has shown that either chronic separation of pups from their mothers during the first 2 weeks of life $(3 \mathrm{~h} / \mathrm{d})$ or single separation on the 9 th postnatal day $(24 \mathrm{~h})$ does not change expression levels of Homer 1 and Homer Ia, Homer $1 b$, and Homer $1 c$ transcripts in the prefrontal cortex of male mice on the 15th postnatal day; however, in adulthood, there is a decrease in total mRNA expression of Homer1 without the change in the ratio of short to long transcripts (unpublished data, NCBI BioProject PRJNA649640). Taken together, our results obtained in mouse models also indicate that the delayed effects of early postnatal stress are present only in males [74]. Diminished total expression of the gene in question could be evidence of the epigenetic changes that occurred in its regulatory regions or in the genes whose protein products are regulators of Homer 1 expression. It was shown using in vitro and in vivo techniques that epigenetic regulation of Homer1 depends on the BDNF-induced signaling [75], which is strongly affected by the early postnatal stress [76, 77]. Thus, stress early in life, in all likelihood, has no direct impact on the HOMER1b/c-Homerla transcription switch but can affect the level of HOMER1 expression, which, in turn, determines the amplitude of this switch.

\section{GENETIC VARIANTS OF HOMER1 ASSOCIATED WITH THE DEVELOPMENT OF DEPRESSION AND OTHER MENTAL DISORDERS}

The data obtained in the genome-wide association studies point to the link between depression and some polymorphisms in the regulatory regions of the HOMER 1 gene $[78,79]$, and there are similar reports regarding suicidal behavior [80, 81]. Functional significance of such polymorphisms is still not fully understood; however, investigators have been able to predict possible transcription factor-binding sites (e.g., for CEBPA, REL, and NFKB1) that can be disrupted by polymorphic substitutions using various bioinformatic approaches [79, 81]. Functional magnetic resonance imaging data have shown that the presence of the rs7713917 polymorphism in humans results in the decreased activation of the prefrontal cortex during expectation of a reward [78] and in increased activation in response to emotional stimulus [82]. These data probably mean reduced level of motivation and increased impulsivity. Furthermore, carriers of this allele switch attention more slowly in response to negative stimuli, possibly indicating an anomaly in the processes of executive control [83]. Aside from the functional changes in carriers of the risk allele (A) of rs7713917, the volume of the medial prefrontal cortex proved to be smaller in these individuals, and indicators of fractional anisotropy in the frontal tract were found to be reduced [82]. Such structural features are suggestive of a myelination decrease, which is often associated with the stress-induced mental disorders [84]. It must be mentioned that the results of postmortem studies show no changes in the HOMER1 expression between those who were depressed when alive and those who were not depressed; only recently, a study revealed that the HOMER Ia level in interneurons of the striatum is higher in the depressed patients compared with the nominally healthy individuals [85]. On the other hand, the regionspecific changes in the expression of MGLUR1 and MGLUR5 are often detectable in the depressed individuals $[5,86]$, which may also indicate aberration of the HOMER1-mediated signaling. Furthermore, the importance of HOMER1 in resistance to mental illness is confirmed by the finding that the carriers of HOMER1 risk alleles are less responsive to the treatment with antidepressants [82, 87]. 


\section{STRESS-INDUCED ACTIVATION OF HOMER1A CAUSES POSTSYNAPTIC-DENSITY REMODELING AND EXERTS NEUROPROTECTIVE ACTION}

The data presented so far indicate that acute stress mostly increases HOMER 1a expression in various regions of the brain, whereas chronic stress most often upregulates isoforms HOMER $1 b$ and/or HOMER1c in the hippocampus. It is noteworthy that these changes in the HOMER1a/HOMER1b/HOMER1c ratio in the hippocampus or prefrontal cortex can determine resistance or susceptibility to stress [65, 67]. These data are in good agreement with the previous studies demonstrating that the induction of Homer la in the cortical structures allows better adaptation to stressful conditions [88] and has a pronounced antidepressant effect [22, 89-91]. Moreover, increase in the Homerla expression is observed during treatment with various pharmaceuticals [22] and during treatment with other modalities, such as transcranial magnetic stimulation [89], electroconvulsive therapy [91], sleep deprivation [91], or phototherapy [90].
Meanwhile, the data on the delayed effects of stress in animals suggest that behavioral disturbances and increased susceptibility to stress may be related to the changes in the total expression of Homer1 rather than to the altered Homerla/Homer1b/Homer1c ratio. Nevertheless, we could hypothesize that it is the delay of Homerla induction that is causing negative effects on behavior because the specific action of this short isoform has been associated with the resistance to stress. Support of our hypothesis could be found in the studies of Homer1 knockout animals, which exhibit decreased exploratory activity, increased anxiety, impaired adaptive behavior in the forced swimming test, and impaired sensorimotor reactions and cognitive functions $[92,93]$. On the other hand, restoration of the expression of only the Homerla isoform in the prefrontal cortex by means of a vector construct eliminates most of the negative effects on behavior observed in these animals [93]. By contrast, restoration of the Homerlb and/or Homerlc expression in the prefrontal cortex does not lead to any behavioral improvement.

What are molecular mechanisms of these effects of HOMER 1a? There is no exact answer to date. Given that
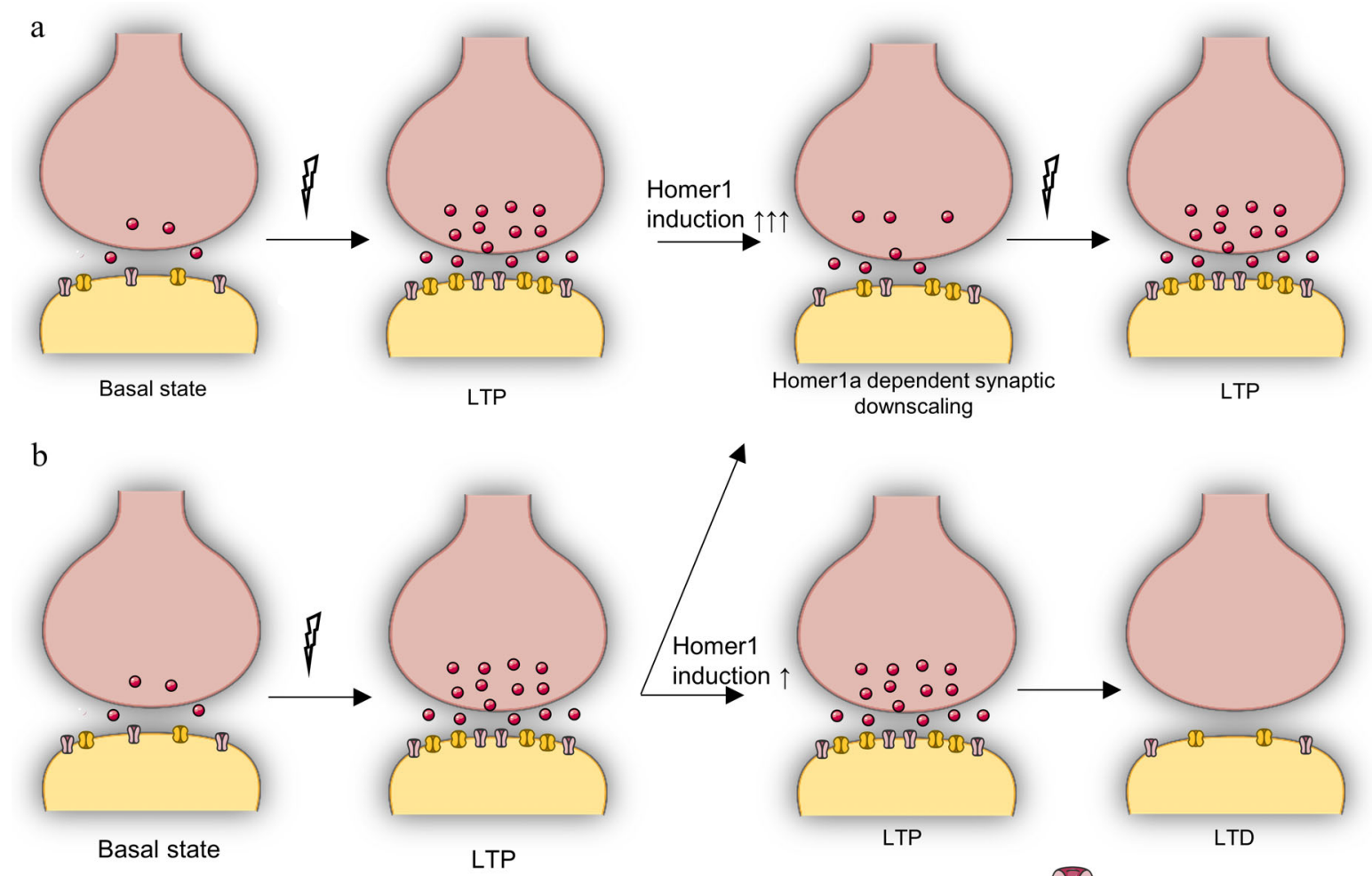

G Glutamate

NMDAR

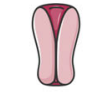

AMPAR

Fig. 3. Putative role of Homerla-dependent remodeling in stress resistance and in synaptic transmission. a) Reversible repression (downscaling) of synaptic transmission occurs with strong upregulation of HOMER1a ( $\uparrow \uparrow$ ) in response to LTP, which is necessary to protect the cell from excessive activation of glutamatergic transmission and to adapt the cell to subsequent LTP. This pattern is typical for stress-resistant individuals or for individuals exposed to short-term stress. b) HOMER1a-dependent activity reduction (downscaling) is observed in response to LTP only in some synapses with weak HOMER 1a upregulation $(\uparrow)$, while other synapses continue to be in the LTP state, after which an LTD phase inevitably begins, which is accompanied by deeper inhibition of synaptic transmission. This pattern is characteristic for stress-susceptible individuals and individuals under chronic stress. 
HOMER1b,c can modulate various forms of synaptic plasticity, but in contrast, HOMER1a does not drive remodeling of the postsynaptic density, it can be assumed that the effects of these isoforms cannot be explained by altered synaptic-transmission velocity alone. Recent reports suggest that the antidepressant action of the Homerla induction is explained by the activation of the ERK signaling cascade, both through the BDNFRas-ERK and A1R-ERK1/2 pathways [22]. Another work [65] indicates that the increased susceptibility to stress is related to the PERK-eIF2 $\alpha$ pathway activity in the hippocampus. It must be pointed out that the Homerla induction in different brain structures, such as prefrontal cortex and hippocampus, could play opposite roles in the stress-induced depressive behavior [94]. Moreover, the impact of HOMER1a on stress susceptibility may also depend on the degree of specificity of Homer $1 a$ expression induction (on whether it is activated specifically in only one brain region or in several at once) [95].

Interestingly enough, the suppression of LTP and of synaptic transmission under the effect of HOMER1a induction is not exactly consistent with the generally accepted concept of a stress-induced biphasic change in the glutamatergic transmission activity [96-98]. This concept implies that acute stress enhances the glutamate release and incorporation of AMPA and NMDA receptors into the postsynaptic membrane, whereas chronic stress is associated with the decrease in the number of glutamate receptors on the postsynaptic membrane and with suppression of the glutamate signal transduction. Possible explanations for the discrepancy in the effects of HOMER1a expression activation on AMPA receptor signaling could be different time profiles of the stress response [99] and the so-called biphasic remodeling of postsynaptic-membrane architecture [100]. The latter suggests that the prolonged stimulation with glutamate leads initially (after 30-60 min) to disruption of the HOMER1b,c-containing postsynaptic clusters, but increase in the density of such clusters is observed (relative to baseline) 4-8 $\mathrm{h}$ after. In this context, the HOMER1a-dependent remodeling can be regarded as an important participant in the "switching" of synaptic transmission, whereas Homer la induction can be considered as a cell adaptation to aberrant activation of glutamatergic transmission; thus, HOMER1a can play a neuroprotective role. The results of in vitro studies on neuronal cultures have revealed that Homerla protects neurons from NMDA-mediated damage, which speaks in favor of such suggestion [101]. Furthermore, both overexpression of Homerla and downregulation of Homer $1 b$ and/or Homer lc suppress apoptosis in the neurons subjected to traumatic treatments, enhance cell viability, and stimulate autophagy processes [102, 103]. The importance of HOMERla as a neuroprotective agent is also confirmed by the observation that it plays a considerable part in the homeostatic synaptic plasticity during sleep; this plasticity includes removal of AMPA receptors from the postsynaptic membrane and LTP inhibition, which results in the decrease in the number of excitatory synapses [104]. Nonetheless, although HOMER1a causes suppression of LTP, the HOMERla-mediated changes of suppression of synaptic transmission (downscaling) are reversible and less pronounced in comparison with LTD or depotentiation [36].

Therefore, apparently, the possibility of rapid adaptation of synapses due to the HOMER1a-dependent remodeling of postsynaptic density in response to various stimuli facilitates stability and prevention of the stronger inhibition of synaptic transmission in the neural networks (Fig. 3) responsible for the psycho-emotional state. In this context, upregulation of HOMER1b and/or HOMER1c expression induced by chronic stress may be a consequence rather than cause of the reduced glutamatergic signaling and the level of the activity-induced HOMER la expression.

Funding. This work was financially supported by the Russian Science Foundation (grant no. 16-15-10131).

Ethics declarations. The authors declare no conflicts of interest in financial or any other sphere. This article does not contain any studies with human participants or animals performed by any of the authors.

Open access. This article is licensed under a Creative Commons Attribution 4.0 International License, which permits use, sharing, adaptation, distribution and reproduction in any medium or format, as long as you give appropriate credit to the original author(s) and the source, provide a link to the Creative Commons license, and indicate if changes were made. The images or other third party material in this article are included in the article's Creative Commons license, unless indicated otherwise in a credit line to the material. If material is not included in the article's Creative Commons license and your intended use is not permitted by statutory regulation or exceeds the permitted use, you will need to obtain permission directly from the copyright holder. To view a copy of this license, visit http://creativecommons.org/licenses/ by $/ 4.0 /$.

\section{REFERENCES}

1. Qiao, H., Li, M. X., Xu, C., Chen, H. B., An, S. C., and Ma, X. M. (2016) Dendritic spines in depression: what we learned from animal models, Neural Plast., 2016, 8056370, doi: $10.1155 / 2016 / 8056370$.

2. Musazzi, L., Treccani, G., and Popolil, M. (2015) Functional and structural remodeling of glutamate synapses in prefrontal and frontal cortex induced by behavioral stress, Front. Psychiatry, 6, 60, doi: 10.3389/Fpsyt.2015.00060.

3. Sanacora, G., Treccani, G., and Popoli, M. (2012) Towards a glutamate hypothesis of depression: an emerging frontier 
of neuropsychopharmacology for mood disorders, Neuropharmacology, 62, 63-77, doi: 10.1016/j.neuropharm. 2011.07.036.

4. Gulyaeva, N. V. (2017) Interplay between brain BDNF and glutamatergic systems: a brief state of the evidence and association with the pathogenesis of depression, Biochemistry (Moscow), 82, 301-307, doi: 10.1134/ S0006297917030087.

5. Deschwanden, A., Karolewicz, B., Feyissa, A. M., Treyer, V., Ametamey, S. M., et al. (2011) Reduced metabotropic Glutamate receptor 5 density in major depression determined by [C-11]ABP688 positron emission tomography and postmortem study, Curr. Neuropharmacol., 9, 15-15.

6. Tsai, G. C., and Coyle, J. T. (2002) Glutamatergic mechanisms in schizophrenia, Annu. Rev. Pharmacol., 42, 165179, doi: 10.1146/annurev.pharmtox.42.082701.160735.

7. Engmann, O., Hortobágyi, T., Pidsley, R., Troakes, C., Bernstein, H. G., et al. (2011) Schizophrenia is associated with dysregulation of a $\mathrm{Cdk} 5$ activator that regulates synaptic protein expression and cognition, Brain J. Neurol., 134, 2408-2421, doi: 10.1093/brain/awr155.

8. Matosin, N., Fernandez-Enright, F., Lum, J. S., Engel, M., Andrews, J. L., et al. (2016) Molecular evidence of synaptic pathology in the CA1 region in schizophrenia, Npj Schizophr., 2, 16022, doi: 10.1038/Npjschz.2016.22.

9. Fatemi, S. H., Folsom, T. D., Kneeland, R. E., Yousefi, M. K., Liesch, S. B., and Thuras, P. D. (2013) Impairment of fragile $\mathrm{X}$ mental retardation protein-metabotropic glutamate receptor 5 signaling and its downstream cognates rasrelated $\mathrm{C} 3$ botulinum toxin substrate 1 , amyloid beta A4 precursor protein, striatal-enriched protein tyrosine phosphatase, and homer 1, in autism: a postmortem study in cerebellar vermis and superior frontal cortex, Mol. Autism, 4, 21, doi: 10.1186/2040-2392-4-21.

10. Tu, J. C., Xiao, B., Yuan, J. P., Lanahan, A. A., Leoffert, K., et al. (1998) Homer binds a novel proline-rich motif and links group 1 metabotropic glutamate receptors with IP3 receptors, Neuron, 21, 717-726, doi: 10.1016/ S0896-6273(00)80589-9.

11. Nakamura, M., Sato, K., Fukaya, M., Araishi, K., Aiba, A., et al. (2004) Signaling complex formation of phospholipase $\mathrm{C}$ beta 4 with metabotropic glutamate receptor type 1 alpha and 1,4,5-trisphosphate receptor at the perisynapse and endoplasmic reticulum in the mouse brain, Eur. J. Neurosci., 20, 2929-2944, doi: 10.1111/j.14609568.2004.03768.x.

12. Hwang, J. I., Kim, H. S., Lee, J. R., Kim, E., et al. (2005) The interaction of phospholipase C-beta 3 with Shank2 regulates mGluR-mediated calcium signal, J. Biol. Chem., 280, 12467-12473, doi: 10.1074/jbc.M410740200.

13. Yuan, J. P., Kiselyov, K., Shin, D. M., Chen, J., Shcheynikov, N., et al. (2003) Homer binds TRPC family channels and is required for gating of TRPC1 by IP3 receptors, Cell, 114, 777-789, doi: 10.1016/S0092-8674(03)00716-5.

14. Kim, J. Y., Zeng, W. Z., Kiselyov, K., Yuan, J. P., Dehoff, M. H., et al. (2006) Homer 1 mediates store- and inositol 1,4,5-trisphosphate receptor-dependent translocation and retrieval of TRPC3 to the plasma membrane, J. Biol. Chem., 281, 32540-32549, doi: 10.1074/jbc.M602496200.

15. Hwang, S. Y., Wei, J., Westhoff, J. H., Duncan, R. S., Ozawa, F., et al. (2003) Differential functional interaction of two Vesl/Homer protein isoforms with ryanodine recep- tor type 1: a novel mechanism for control of intracellular calcium signaling, Cell Calcium, 34, 177-184, doi: 10.1016/ S0143-4160(03)00082-4.

16. Yamamoto, K., Sakagami, Y., Sugiura, S., Inokuchi, K., Shimohama, S., and Kato, N. (2005) Homer 1a enhances spike-induced calcium influx via L-type calcium channels in neocortex pyramidal cells, Eur. J. Neurosci., 22, 13381348, doi: $10.1111 /$ j.1460-9568.2005.04278.x.

17. Hu, J. H., Park, J. M., Park, S., Xiao, B., Dehoff, M. H., et al. (2010) Homeostatic scaling requires group I mGluR activation mediated by Homer1a, Neuron, 68, 1128-1142, doi: 10.1016/j.neuron.2010.11.008.

18. Clifton, N. E., Trent, S., Thomas, K. L., and Hall, J. (2019) Regulation and function of activity-dependent homer in synaptic plasticity, Mol. Neuropsychiatry, 5, 147161, doi: 10.1159/000500267.

19. Orlowski, D., Elfving, B., Müller, H. K., Wegener, G., and Bjarkam, C. R. (2012) Wistar rats subjected to chronic restraint stress display increased hippocampal spine density paralleled by increased expression levels of synaptic scaffolding proteins, Stress, 15, 514-523, doi: 10.3109/ 10253890.2011 .643516$.

20. Wagner, K. V., Hartmann, J., Mangold, K., Wang, X. D., Labermaier, C., et al. (2013) Homer1 mediates acute stressinduced cognitive deficits in the dorsal hippocampus, $J$. Neuroscience, 33, 3857-3864, doi: 10.1523/Jneurosci.433312.2013 .

21. Buonaguro, E. F., Morley-Fletcher, S., Avagliano, C., Vellucci, L., Iasevoli, F., et al. (2020) Glutamatergic postsynaptic density in early life stress programming: Topographic gene expression of mGlu5 receptors and Homer proteins, Prog. Neuro Psychoph., 96, 109725, doi: 10.1016/J.Pnpbp.2019.109725.

22. Serchov, T., Heumann, R., van Calker, D., and Biber, K. (2016) Signaling pathways regulating Homerla expression: implications for antidepressant therapy, Biol. Chem., 397, 207-214, doi: 10.1515/hsz-2015-0267.

23. Shiraishi-Yamaguchi, Y., and Furuichi, T. (2007) The Homer family proteins, Genome Biol., 8, 206, doi: 10.1186/Gb-2007-8-2-206.

24. Flavell, S. W., Kim, T. K., Gray, J. M., Harmin, D. A., Hemberg, M., et al. (2008) Genome-wide analysis of MEF2 transcriptional program reveals synaptic target genes and neuronal activity-dependent polyadenylation site selection, Neuron, 60, 1022-1038, doi: 10.1016/j.neuron.2008.11.029.

25. Irie, K., Nakatsu, T., Mitsuoka, K., Miyazawa, A., Sobue, K., et al. (2002) Crystal structure of the homer 1 family conserved region reveals the interaction between the EVH1 domain and own proline-rich motif, J. Mol. Biol., 318, 1117-1126, doi: 10.1016/S0022-2836(02)00170-5.

26. Xiao, B., Tu, J. C., Petralia, R. S., Yuan, J. P., Doan, A., et al. (1998) Homer regulates the association of group 1 metabotropic glutamate receptors with multivalent complexes of Homer-related, synaptic proteins, Neuron, 21, 707-716, doi: 10.1016/S0896-6273(00)80588-7.

27. Bottai, D., Guzowski, J. F., Schwarz, M. K., Kang, S. H., Xiao, B., et al. (2002) Synaptic activity-induced conversion of intronic to exonic sequence in Homer 1 immediate early gene expression, J. Neuroscience, 22, 167-175, doi: 10.1523/ Jneurosci.22-01-00167.2002.

28. Shaw, G., and Kamen, R. (2012) A conserved AU sequence from the 3' untranslated region of GM-CSF mRNA medi- 
ates selective mRNA degradation, J. Immunol., 189, 5-13.

29. Hermey, G., Mahlke, C., Gutzmann, J. J., Schreiber, J., Bluthgen, N., and Kuhl, D. (2013) Genome-wide profiling of the activity-dependent hippocampal transcriptome, PLoS One, 8, e76903, doi: 10.1371/journal.pone.0076903.

30. Worley, P. F., Zeng, W. Z., Huang, G. J., Kim, J. Y., Shin, D. M., et al. (2007) Homer proteins in $\mathrm{Ca}^{2+}$ signaling by excitable and non-excitable cells, Cell Calcium, 42, 363371, doi: 10.1016/j.ceca.2007.05.007.

31. Brakeman, P. R., Lanahan, A. A., O’Brien, R., Roche, K., Barnes, C. A., et al. (1997) Homer: a protein that selectively binds metabotropic glutamate receptors, Nature, 386, 284-288, doi: 10.1038/386284a0.

32. Le Duigou, C., and Kullmann, D. M. (2011) Group I mGluR agonist-evoked long-term potentiation in hippocampal oriens interneurons, J. Neuroscience, 31, 57775781, doi: 10.1523/Jneurosci.6265-10.2011.

33. Ronesi, J. A., and Huber, K. M. (2008) Homer interactions are necessary for metabotropic glutamate receptor-induced long-term depression and translational activation, J. Neuroscience, 28, 543-547, doi: 10.1523/Jneurosci.501907.2008.

34. Bellone, C., Lüscher, C., and Mameli, M. (2008) Mechanisms of synaptic depression triggered by metabotropic glutamate receptors, Cell. Mol. Life Sci., 65, 2913-2923, doi: 10.1007/s00018-008-8263-3.

35. Lüscher, C., and Huber, K. M. (2010) Group 1 mGluRdependent synaptic long-term depression: mechanisms and implications for circuitry and disease, Neuron, 65, 445-459, doi: 10.1016/j.neuron.2010.01.016.

36. Jones, O. D. (2017) Do group I metabotropic glutamate receptors mediate LTD? Neurobiol. Learn Mem., 138, 8597, doi: 10.1016/j.nlm.2016.08.010.

37. Saugstad, J. A., and Ingram, S. L. (2008) Group I Metabotropic glutamate receptors (mGlu1 and mGlu5), in The Glutamate Receptors, Humana Press, pp. 387-463.

38. Niswender, C. M., and Conn, P. J. (2010) Metabotropic glutamate receptors: physiology, pharmacology, and disease, Annu. Rev. Pharmacol., 50, 295-322, doi: 10.1146/ annurev.pharmtox.011008.145533.

39. Mao, L. M., Yang, L., Tang, Q. S., Samdani, S., Zhang, G. C., and Wang, J. Q. (2005) The scaffold protein homer1b/c links metabotropic glutamate receptor 5 to extracellular signal-regulated protein kinase cascades in neurons, J. Neuroscience, 25, 2741-2752, doi: 10.1523/ Jneurosci.4360-04.2005.

40. Baudry, M., Greget, R., Pernot, F., Bouteiller, J.-M., and $\mathrm{Bi}, \mathrm{Xi}$. (2012) Roles of group I metabotropic glutamate receptors under physiological conditions and in neurodegeneration, WIREs Membr. Transp. Signal., 1, 523-532.

41. Holbro, N., Grunditz, A., and Oertner, T. G. (2009) Differential distribution of endoplasmic reticulum controls metabotropic signaling and plasticity at hippocampal synapses, Proc. Natl. Acad. Sci. USA, 106, 15055-15060, doi: 10.1073/pnas.0905110106.

42. Hayashi, M. K., Tang, C. Y., Verpelli, C., Narayanan, R., Stearns, M. H., et al. (2009) The postsynaptic density proteins homer and shank form a polymeric network structure, Cell, 137, 159-171, doi: 10.1016/j.cell.2009.01.050.

43. Tu, J. C., Xiao, B., Naisbitt, S., Yuan, J. P., Petralia, R. S., et al. (1999) Coupling of mGluR/Homer and PSD-95 com- plexes by the shank family of postsynaptic density proteins, Neuron, 23, 583-592, doi: 10.1016/S0896-6273(00)80810-7.

44. Sala, C., Roussignol, G., Meldolesi, J., and Fagni, L. (2005) Key role of the postsynaptic density scaffold proteins shank and homer in the functional architecture of $\mathrm{Ca}^{2+}$ homeostasis at dendritic spines in hippocampal neurons, J. Neuroscience, 25, 4587-4592, doi: 10.1523/ Jneurosci.4822-04.2005.

45. Sala, C., Piëch, V., Wilson, N. R., Passafaro, M., Liu, G. S., and Sheng, M. (2001) Regulation of dendritic spine morphology and synaptic function by Shank and Homer, Neuron, 31, 115-130, doi: 10.1016/S0896-6273(01)00339-7.

46. Sala, C., Futai, K., Yamamoto, K., Worley, P. F., Hayashi, Y., and Sheng, M. (2003) Inhibition of dendritic spine morphogenesis and synaptic transmission by activityinducible protein homer1a, J. Neuroscience, 23, 6327-6337.

47. Ango, F., Prézeau, L., Muller, T., Tu, J. C., Xiao, B., et al. (2001) Agonist-independent activation of metabotropic glutamate receptors by the intracellular protein Homer, Nature, 411, 962-965, doi: 10.1038/35082096.

48. Bertaso, F., Roussignol, G., Worley, P., Bockaert, J., Fagni, L., and Ango, F. (2010) Homerla-dependent crosstalk between NMDA and metabotropic glutamate receptors in mouse neurons, PLoS One, 5, e9755, doi: 10.1371/journal.pone.0009755.

49. Moutin, E., Raynaud, F., Roger, J., Pellegrino, E., Homburger, V., et al. (2012) Dynamic remodeling of scaffold interactions in dendritic spines controls synaptic excitability, J. Cell Biol., 198, 251-263, doi: 10.1083/ jcb.201110101.

50. Cingolani, L. A., Vitale, C., and Dityatev, A. (2019) Intraand extracellular pillars of a unifying framework for homeostatic plasticity: a crosstalk between metabotropic receptors and extracellular matrix, Front. Cell. Neurosci., 13, 513, doi: 10.3389/Fncel.2019.00513.

51. Thomazeau, A., Bosch, M., Essayan-Perez, S., Barnes, S. A., De Jesus-Cortes, H., and Bear, M. F. (2020) Dissociation of functional and structural plasticity of dendritic spines during NMDAR and mGluR-dependent longterm synaptic depression in wild-type and fragile $\mathrm{X}$ model mice, Mol. Psychiatry, doi: 10.1038/s41380-020-0821-6.

52. Turrigiano, G. G., and Nelson, S. B. (2004) Homeostatic plasticity in the developing nervous system, Nat. Rev. Neurosci., 5, 97-107, doi: 10.1038/nrn1327.

53. Celikel, T., Marx, V., Freudenberg, F., Zivkovic, A., Resnik, E., et al. (2007) Select overexpression of Homerla in dorsal hippocampus impairs spatial working memory, Front. Neurosci., 1, 97-110, doi: 10.3389/neuro.01.1.1. 007.2007.

54. Rozov, A., Zivkovic, A. R., and Schwarz, M. K. (2012) Homerl gene products orchestrate $\mathrm{Ca}(2+)$-permeable AMPA receptor distribution and LTP expression, Front. Synap. Neurosci., 4, 4, doi: 10.3389/fnsyn.2012.00004.

55. Hennou, S., Kato, A., Schneider, E. M., Lundstrom, K., Gähwiler, B. H., et al. (2003) Homer-1a/Vesl-1S enhances hippocampal synaptic transmission, Eur. J. Neurosci., 18, 811-819, doi: 10.1046/j.1460-9568.2003.02812.x.

56. Holz, A., Mülsch, F., Schwarz, M. K., Hollmann, M., Dobrossy, M. D., et al. (2019) Enhanced mGlu5 signaling in excitatory neurons promotes rapid antidepressant effects via AMPA receptor activation, Neuron, 104, 338-352, doi: 10.1016/j.neuron.2019.07.011. 
57. Diering, G. H., and Huganir, R. L. (2018) The AMPA receptor code of synaptic plasticity, Neuron, 100, 314-329, doi: 10.1016/j.neuron.2018.10.018.

58. Okada, D., Ozawa, F., and Inokuchi, K. (2009) Input-specific spine entry of soma-derived Vesl-1S protein conforms to synaptic tagging, Science, 324, 904-909, doi: 10.1126/ science.1171498.

59. Clifton, N. E., Cameron, D., Trent, S., Sykes, L. H., Thomas, K. L., and Hall, J. (2017) Hippocampal regulation of postsynaptic density Homer1 by associative learning, Neural Plast., 2017, 5959182, doi: 10.1155/2017/5959182.

60. Mahan, A. L., Mou, L. P., Shah, N., Hu, J. H., Worley, P. F., and Ressler, K. J. (2012) Epigenetic modulation of Homerla transcription regulation in amygdala and hippocampus with pavlovian fear conditioning, J. Neurosci., 32, 4651-4659, doi: 10.1523/Jneurosci.3308-11.2012.

61. Qi, C., Roseboom, P. H., Nanda, S. A., Lane, J. C., Speers, J. M., and Kalin, N. H. (2010) Anxiety-related behavioral inhibition in rats: a model to examine mechanisms underlying the risk to develop stress-related psychopathology, Genes Brain Behav., 9, 974-984, doi: 10.1111/j.1601183X.2010.00636.x.

62. Nava, N., Treccani, G., Müller, H. K., Popoli, M., Wegener, G., and Elfving, B. (2017) The expression of plasticity-related genes in an acute model of stress is modulated by chronic desipramine in a time-dependent manner within medial prefrontal cortex, Eur. Neuropsychopharm, 27, 19-28, doi: 10.1016/j.euroneuro.2016.11.010.

63. Müller, H. K., Orlowski, D., Bjarkam, C. R., Wegener, G., and Elfving, B. (2015) Potential roles for Homer1 and Spinophilin in the preventive effect of electroconvulsive seizures on stress-induced CA3c dendritic retraction in the hippocampus, Eur. Neuropsychopharm., 25, 1324-1331, doi: 10.1016/j.euroneuro.2015.04.011.

64. Wagner, K. V., Hartmann, J., Labermaier, C., Hausl, A. S., Zhao, G. J., Harbich, D., et al. (2015) Homer1/mGluR5 activity moderates vulnerability to chronic social stress, Neuropsychopharmacology, 40, 1222-1233, doi: 10.1038/ npp.2014.308.

65. Li, M. X., Li, Q., Sun, X. J., Luo, C., Li, Y., et al. (2019) Increased Homer1-mGluR5 mediates chronic stressinduced depressive-like behaviors and glutamatergic dysregulation via activation of PERK-eIF2alpha, Prog. Neuropsychopharmacol. Biol. Psychiatry, 95, 109682, doi: 10.1016/j.pnpbp.2019.109682.

66. Zuo, C. C., Cao, H., Ding, F. F., Zhao, J. L., Huang, Y. Q., et al. (2020) Neuroprotective efficacy of different levels of high-frequency repetitive transcranial magnetic stimulation in mice with CUMS-induced depression: involvement of the $\mathrm{p} 11 / \mathrm{BDNF} /$ Homerla signaling pathway, J. Psychiatr. Res., 125, 152-163, doi: 10.1016/ j.jpsychires.2020.03.018.

67. Reshetnikov, V. V., Kisaretova, P. E., Ershov, N. I., Merkulova, T. I., and Bondar, N. P. (2020) Social defeat stress in adult mice causes alterations in gene expression, alternative splicing, and the epigenetic landscape of H3K4me3 in the prefrontal cortex: an impact of early-life stress, Prog. Neuropsychopharmacol. Biol. Psychiatry, 106, 110068, doi: 10.1016/j.pnpbp.2020.110068.

68. Orsetti, M., Di Brisco, F., Canonico, P. L., Genazzani, A. A., and Ghi, P. (2008) Gene regulation in the frontal cortex of rats exposed to the chronic mild stress paradigm, an animal model of human depression, Eur. J. Neurosci., 27, 2156-2164, doi: 10.1111/j.1460-9568.2008.06155.x.

69. Palmfeldt, J., Henningsen, K., Eriksen, S. A., Müller, H. K., and Wiborg, O. (2016) Protein biomarkers of susceptibility and resilience to stress in a rat model of depression, Mol. Cell. Neurosci., 74, 87-95, doi: 10.1016/j.mcn. 2016.04.001.

70. Burns, S. B., Almeida, D., and Turecki, G. (2018) The epigenetics of early life adversity: current limitations and possible solutions, Prog. Mol. Biol. Transl., 157, 343-425, doi: 10.1016/bs.pmbts.2018.01.008.

71. Turecki, G., Ota, V. K., Belangero, S. I., Jackowski, A., and Kaufman, J. (2014) Early life adversity, genomic plasticity, and psychopathology, Lancet Psychiat., 1, 461-466, doi: 10.1016/S2215-0366(14)00022-4.

72. Montes-Rodriguez, C. J., Lapointe, V., Trivedi, V., Lu, Q., Demchuk, A. M., and McNaughton, B. L. (2013) Postnatal development of Homerla in the rat hippocampus, Hippocampus, 23, 890-902, doi: 10.1002/hipo.22146.

73. Ary, A. W., Aguilar, V. R., Szumlinski, K. K., and Kippin, T. E. (2007) Prenatal stress alters limbo-corticostriatal Homer protein expression, Synapse, 61, 938-941, doi: 10.1002/syn.20439.

74. Ryabushkina, Y. A., Reshetnikov, V. V., and Bondar, N. P. (2020) Maternal Separation early in life alters the expression of genes Npas 4 and Nr1d 1 in adult female mice: correlation with social behavior, Behav. Neurol., 2020, 7830469, doi: 10.1155/2020/7830469.

75. Ji, Y., Lu, Y., Yang, F., Shen, W., Tang, T. T., et al. (2010) Acute and gradual increases in BDNF concentration elicit distinct signaling and functions in neurons, Nat. Neurosci., 13, 302-309, doi: 10.1038/nn.2505.

76. Bondar, N. P., and Merkulova, T. I. (2016) Brain-derived neurotrophic factor and early-life stress: multifaceted interplay, J. Biosciences, 41, 751-758, doi: 10.1007/s12038-0169648-3.

77. Roth, T. L., and Sweatt, J. D. (2011) Epigenetic marking of the BDNF gene by early-life adverse experiences, Horm. Behav., 59, 315-320, doi: 10.1016/j.yhbeh.2010.05.005.

78. Rietschel, M., Mattheisen, M., Frank, J., Treutlein, J., Degenhardt, F., et al. (2010) Genome-wide association-, replication-, and neuroimaging study implicates HOMER1 in the etiology of major depression, Biol. Psychiat., 68, 578585, doi: 10.1016/j.biopsych.2010.05.038.

79. Rao, S. T., Leung, C. S. T., Lam, M. H., Wing, Y. K., Waye, M. M. Y., and Tsui, S. K. W. (2017) Resequencing three candidate genes discovers seven potentially deleterious variants susceptibility to major depressive disorder and suicide attempts in Chinese, Gene, 603, 34-41, doi: 10.1016/ j.gene.2016.12.006.

80. Strauss, J., McGregor, S., Freeman, N., Tiwari, A., George, C. J., et al. (2012) Association study of earlyimmediate genes in childhood-onset mood disorders and suicide attempt, Psychiatry Res., 197, 49-54, doi: 10.1016/j.psychres.2011.11.022.

81. Rao, S. T., Lam, M. H. B., Yeung, V. S. Y., Wing, Y. K., and Waye, M. M. Y. (2016) Association of HOMER1 rs2290639 with suicide attempts in Hong Kong Chinese and the potentially functional role of this polymorphism, Springerplus, 5, 767, doi: 10.1186/S40064-016-2404-1.

82. Benedetti, F., Poletti, S., Locatelli, C., Mazza, E., Lorenzi, C., et al. (2018) A Homer 1 gene variant influ- 
ences brain structure and function, lithium effects on white matter, and antidepressant response in bipolar disorder: a multimodal genetic imaging study, Prog. Neuro Psychoph., 81, 88-95, doi: 10.1016/j.pnpbp.2017.10.011.

83. Wells, T. T., Judah, M. R., Ellis, A. J., McGeary, J. E., and Beevers, C. G. (2015) Inhibition of attention for affective material: contributions by HOMER1 gene variation, Psychol. Neurosci., 8, 495-508, doi: 10.1037/pne0000027.

84. Antontseva, E., Bondar, N., Reshetnikov, V., and Merkulova, T. (2020) The effects of chronic stress on brain myelination in humans and in various rodent models, Neuroscience, 441, 226-238, doi: 10.1016/j.neuroscience. 2020.06.013.

85. Leber, S. L., Llenos, I. C., Miller, C. L., Dulay, J. R., Haybaeck, J., and Weis, S. (2017) Homerla protein expression in schizophrenia, bipolar disorder, and major depression, J. Neural Transm., 124, 1261-1273, doi: 10.1007/ s00702-017-1776-x.

86. Bernard, R., Kerman, I. A., Thompson, R. C., Jones, E. G., Bunney, W. E., et al. (2011) Altered expression of glutamate signaling, growth factor, and glia genes in the locus coeruleus of patients with major depression, Mol. Psychiatry, 16, 634-646, doi: 10.1038/mp.2010.44.

87. Ising, M., Lucae, S., Binder, E. B., Bettecken, T., Uhr, M., et al. (2009) A genomewide association study points to multiple loci that predict antidepressant drug treatment outcome in depression, Arch. Gen. Psychiatry, 66, 966-975, doi: 10.1001/archgenpsychiatry.2009.95.

88. Szumlinski, K. K., Kalivas, P. W., and Worley, P. F. (2006) Homer proteins: implications for neuropsychiatric disorders, Curr. Opin. Neurobiol., 16, 251-257, doi: 10.1016/ j.conb.2006.05.002.

89. Sun, P., Wang, F. R., Wang, L., Zhang, Y., Yamamoto, R., et al. (2011) Increase in cortical pyramidal cell excitability accompanies depression-like behavior in mice: a transcranial magnetic stimulation study, J. Neurosci., 31, 1646416472, doi: 10.1523/Jneurosci.1542-11.2011.

90. Sun, P., Zhang, Q., Zhang, Y., Wang, F. R., Chen, R., et al. (2015) Homerla-dependent recovery from depression-like behavior by photic stimulation in mice, Physiol. Behav., 147, 334-341, doi: 10.1016/j.physbeh.2015.05.007.

91. Conti, B., Maier, R., Barr, A. M., Morale, M. C., Lu, X., et al. (2007) Region-specific transcriptional changes following the three antidepressant treatments electro convulsive therapy, sleep deprivation and fluoxetine, Mol. Psychiatry, 12, 167-189, doi: 10.1038/sj.mp.4001897.

92. Szumlinski, K. K., Lominac, K. D., Kleschen, M. J., Oleson, E. B., Dehoff, M. H., et al. (2005) Behavioral and neurochemical phenotyping of Homer1 mutant mice: possible relevance to schizophrenia, Genes Brain Behav., 4, 273-288, doi: 10.1111/j.1601-183X.2005.00120.x.

93. Lominac, K. D., Oleson, E. B., Pava, M., Klugmann, M., Schwarz, M. K., et al. (2005) Distinct roles for different Homer1 isoforms in behaviors and associated prefrontal cor- tex function, J. Neurosci., 25, 11586-11594, doi: 10.1523/ Jneurosci.3764-05.2005.

94. Serchov, T., Schwarz, I., Theiss, A., Sun, L., Holz, A., et al. (2020) Enhanced adenosine A1 receptor and Homerla expression in hippocampus modulates the resilience to stress-induced depression-like behavior, Neuropharma-cology, 162, 107834, doi: 10.1016/j.neuropharm.2019.107834.

95. Albert, P. R. (2019) Targeting Homerla for rapid antidepressant effects, Neuron, 104, 182-183, doi: 10.1016/ j.neuron.2019.10.003.

96. Treccani, G., Musazzi, L., Perego, C., Milanese, M., Nava, N., et al. (2014) Stress and corticosterone increase the readily releasable pool of glutamate vesicles in synaptic terminals of prefrontal and frontal cortex, Mol. Psychiatry, 19, 433-443, doi: 10.1038/mp.2014.5.

97. Musazzi, L., Tornese, P., Sala, N., and Popoli, M. (2017) Acute stress is not acute: sustained enhancement of glutamate release after acute stress involves readily releasable pool size and synapsin I activation, Mol. Psychiatry, 22, 1226-1227, doi: 10.1038/mp.2016.175.

98. Popoli, M., Yan, Z., McEwen, B. S., and Sanacora, G. (2012) The stressed synapse: the impact of stress and glucocorticoids on glutamate transmission, Nat. Rev. Neurosci., 13, 22-37, doi: 10.1038/nrn3138.

99. Joëls, M., and Baram, T. Z. (2009) The neuro-symphony of stress, Nat. Rev. Neurosci., 10, 459-466, doi: 10.1038/ nrn2632.

100. Inoue, Y., Udo, H., Inokuchi, K., and Sugiyama, H. (2007) Homerla regulates the activity-induced remodeling of synaptic structures in cultured hippocampal neurons, Neuroscience, 150, 841-852, doi: 10.1016/ j.neuroscience.2007.09.081.

101. Wang, Y., Rao, W., Zhang, C., Zhang, C., Liu, M. D., et al. (2015) Scaffolding protein Homerla protects against NMDA-induced neuronal injury, Cell Death Dis., 6, e1843, doi: 10.1038/cddis.2015.216.

102. Wang, Y., Zhao, M. M., Shang, L., Zhang, Y. G., Huang, C. G., et al. (2020) Homerla protects against neuronal injury via $\mathrm{PI} 3 \mathrm{~K} / \mathrm{AKT} / \mathrm{mTOR}$ signaling pathway, Int. J. Neurosci., 130, 621-630, doi: 10.1080/00207454.2019. 1702535.

103. Fei, F., Rao, W., Zhang, L., Chen, B. G., Li, J., et al. (2014) Downregulation of Homer1b/C improves neuronal survival after traumatic neuronal injury, Neuroscience, 267, 187-194, doi: 10.1016/j.neuroscience.2014.02.037.

104. Diering, G. H., Nirujogi, R. S., Roth, R. H., Worley, P. F., Pandey, A., and Huganir, R. L. (2017) Homerla drives homeostatic scaling-down of excitatory synapses during sleep, Science, 355, 511-515, doi: 10.1126/science.aai8355.

105. Chen, F. H., Polsinelli, B., Nava, N., Treccani, G., Elfving, B., et al. (2020) Structural plasticity and molecular markers in hippocampus of male rats after acute stress, Neuroscience, 438, 100-115, doi: 10.1016/j.neuroscience. 2020.05.001. 